\title{
Trial Summary Parameter Value Code
}

National Cancer Institute

\section{Source}

National Cancer Institute. Trial Summary Parameter Value Code. NCI Thesaurus. Code C117458.

A character or string that represents the trial summary parameter value. 